\title{
The Impact of Higher Education on Environmental Risk Perceptions
}

\author{
Eren Durmuş-Özdemir, Sevinç Şener \\ Akdeniz University, Antalya, Turkey
}

\begin{abstract}
The purpose of the present study is to explain if there is any difference in the environmental risk perceptions of university students and the association of such differences, if any, with environmental education. Nowadays, the importance of education in understanding the risks that threaten the environment and suggesting solutions for such risks and raising awareness on environmental matters has become an important research question. It is known that higher education is the level of education where individuals are able to attain environmental awareness. Hence, it is necessary to investigate the university students' environment risk perceptions related to environment education. The present study is a relational study with a descriptive pattern aimed to describe the relationship between university students' environment risk perceptions and environment education. The "Environmental Risk Perceptions" questionnaire was the basic data collection tool of this study. The questionnaire was tested in a pilot study with 250 university students and it was revised according to the feedback obtained from these students. The revised version of the questionnaire was used in the field study which was conducted through face-to-face interviews with 570 university students actively attending in Vocational College of Technical Sciences of Akdeniz University in Turkey from January 2015 to May 2016. The obtained data from the questionnaires are analyzed through the SPSS statistical package program. The current study found that a significant positive relationship was found between the students' environment education and their environmental risk perceptions. Students responding to the study stated that taking at least 1 course on environment during their university education had an impact on all aspects of their environmental risk perception. The great majority of students expressed that university education had improved their sensitivity towards environmental matters and they knew about the prominent non-governmental organizations active in the field of environment and became members to such organizations owing to their education. The results of the present study indicate that the formal education and non-formal learning processes offered at vocational colleges with respect to matters concerning the environment have an impact upon students. In fact, the present study gives way to the opinion that the addition of courses on environmental matters to all programmers creates a difference in the environmental risk perceptions of students .
\end{abstract}

Keywords: environmental risk, environmental education, university

*The article's abstract was presented at the 8th International Cultural Studies Conference, Environment and Culture, on September 1-3, 2015.

Eren Durmuş-Özdemir, assistant professor, Business Administration Department, Akdeniz University, Antalya, Turkey.

Sevinç Şener, assistant professor, Vocational College of Technical Sciences, Akdeniz University, Antalya, Turkey.

Correspondence concerning this article should be addressed Eren Durmuş-Özdemir, Faculty of Economics and Administrative Sciences, Business Administration Department, Akdeniz University, Antalya, Turkey. 


\section{Introduction}

The aim of the this study is to explain if there is any difference in the environmental risk perceptions of university students and the association of such differences, if any, with environmental education. Environmental risk perception has been an important research field among educators and academic scholars worldwide for a long time. This prolonged and heightened interest in environmental risk perception is prompted by several factors. Especially for developed economies, environmental risk perception can be constructed by providing the type of education that will teach sensitive individuals correct behaviors. Moreover, it is accepted that education is the most effective way to resolve environmental problems (Duan \& Fortner, 2010). It is stated that importance of a quality environmental education and the environmental risk perception education provides for the permanent solution of environmental problems (Monroe, Andrews, \& Biedenweg, 2007). However, it has a more critical role for developing countries since environment awareness is seen as an engine of environmental education progress and social adjustment. Thus, environment education formation is widely encouraged by national educational policies to stimulate social conscious.

The objective expected to be achieved in environmental education was designated at the Intergovernmental Environmental Education Conference held for the first time in Tbilisi through the cooperation between United Nations Education, Scientific, and Cultural Organization (UNESCO) and U.N. Environment Programme (UNEP). The objective of environmental education is defined in the Tbilisi Declaration as training individuals in consciousness, knowledge, attitudes, and skills concerning environmental issues and ensuring their participation in their solution (Tbilisi Declaration, 1977). It is known that environmental education commences in the family and close circle of individuals should be developed further through elementary, secondary, and higher education. Especially, higher education is the level of education where individuals are able to attain environmental awareness. Some studies stressed that raising individuals with environmental risk perception is only possible with an effective higher environmental education (Ateş \& Karatepe, 2013; Selim, Karakuş, Elkan, \& Selim, 2011).

In parallel with developing interest in environmental awareness throughout the world, Turkey has also witnessed an increasing interest in environmental education field both between her academic scholars, and educators. In Turkey, however, it is striking that there is no national policy regarding environmental education at the higher education level, whereas basic knowledge of the environment is offered under different courses in the curricula of elementary and secondary schools (Oğuz, Çakıcı, \& Kavas, 2011). Although there is still a small body of research addressing the issue of environmental education and environmental risk perception with university students in Turkey, it can also be observed that the number of studies is increasing gradually (Çabuk \& Karacaoğlu, 2003; Erdoğan, 2013; Oğuz et al., 2011; Sam, Gürsakal, \& Sam, 2010; Talay, Gündüz, \& Akpınar, 2004). Therefore, it doesn't seem to be possible to suggest that there is a nation-wide standardized educational infrastructure or practice relating to the matters of environment (Oğuz et al., 2011). It can be stated that there is a need to make changes in the high level environmental education provided in Turkey. Setting off from this point, the aim of the present study is to explain whether there are any differences in the environmental risk perceptions of university students and to explain the association between such differences and environmental education, if any. For this purpose, we predicted that "delivery of environmental courses to students affects their environmental risk perceptions"; departments offering education to students affect their environmental risk perceptions" and "the sensitivity of students on environmental matters affects their environmental risk perceptions". 
The paper is organized as follows: The first section summarizes the relevant literature and explains the derivation of the four research hypotheses. The methodology and findings of the field study on a sample of 570 students in the Vocational College of Technical Sciences of Akdeniz University in Turkey are presented in the next section. The findings are discussed and some recommendations are offered for further research in the last section.

\section{Literature Review}

\section{Environmental Risk Perception}

Human beings that form a part of the environment have strived to manage the ecological environment throughout history for their various needs. Productive and consumptive predispositions increased among populations specifically along with the development of the modern consumption society and the environmental balance embarked upon a rapid course of disruption (Kurc1, 2014). Upon the onset of a series of damages to the ecological system, the environment, once managed by humans, started to influence them. Such factors as the rapidly changing environment, increasing environmental pollution and changes in the structure of raw materials for consumption caused humanity to be faced with environmental risks (Ağbuğa, 2016). Environmental risks can be characterized as threats to society that accrue from the interaction of technology and nature. Therefore, it covers a multitude of sins, including air and water pollution, food safety, noise, technological accidents, waste facilities, global warming, acid rain, and ozone depletion. In other words, environmental risks are usually understood as any environmental hazards or processes with potentially negative consequences (Böhm \& Pfister, 2000; Kasperson, Kasperson, \& Dow, 2001).

The concept of environmental risk can be specified as the expression of the results of the impact of any activity or disputation on the environment in general terms and the state of being exposed to such impact (Slimak \& Dietz, 2006), while there is another definition combining an irreversible ecological threat posed by globalization against plants, animals and humans and the state of being systematically faced with such threats arising from the modernization process (Beck, 1992). According to Kasperson et al. (2001) environmental risk is the threat to human beings and what they value from natural or human-driven hazards associated with global change. It is rather difficult to interpret the concept of risk for the environment and for activities concerning the environment and such interpretation requires a different perspective (Kahraman, 2002). Hence, risks from environmental change can be perceptible different perspectives. For example, Duan and Fortner (2010, p. 2) stated that environment risk should be analyzed by social, economic, cultural, and political perspectives to explore public concerns, such as how risks are framed in social processes or how the public responds to and evaluates various environmental risks. Thus it needs to explain not only physical processes, but also public perceptions to provide more insights for environmental risk management. At the centre of this debate, the concept of environmental risk perception has been playing a key role as it could be considered the central part of environmental risks.

Despite the plurality of environmental risk perception in the literature, there is no global consensus on exact definition of the term. Some scholars described environmental risk perception as traditional pollution-based environmental issues form industry, agriculture; as human activities that directly or indirectly contribute to ecological systems degradation; as resource shortage; as global environmental issues and dynamic processes (Lai \& Tao, 2003; Slimak \& Dietz, 2006; Steg \& Sievers, 2000). In other studies, environmental risk perception has been defined as a subjective judgment that people make about the characteristics of 
environmental risks (Anantho, 2008; Zhang et al., 2012). For this reason, there are a number of studies that have investigated the perceptions of environmental risk that concern socio-cultural and demographics factors (Fernández-Manzanal, Rodríguez-Barreiro, \& Carrasquer, 2007; Riechard \& Peterson, 1998; Van der Linden, 2015). For example, the empirical study conducted by Riechard and Peterson (1998) demonstrated significantly higher perceptions of risk among females as opposed to males for environmental hazards.

Relevant academic studies underline the fact that education is the other important social variable in the process of improving environmental risk perception (Duan \& Fortner, 2010; Payne, 2016; Sam et al., 2010). Environmental education is defined as the process of training prevalent, creative, responsible, collaborative, and environmentally literate citizens in a democratic society. Although issue of socio-cultural and demographics factors and their influence on perceptions of environmental risk has been examined for more than 30 years, recent researches are still interested in issue of whether environmental education can affect environmental risk perception (Young, Kuob, \& Chiangc, 2015).These studies express that individuals with education and sensitivity assume more active roles in the solution of environmental issues. For example, Sam et al. (2010) stated that university students' environmental risk perceptions were high and there was a strong positive relationship between their environmental risk perceptions and environmental attitudes. However, as one of the social variables, environmental education is considered to be a factor of significance in raising sensitivity on environmental matters among individuals (Duan \& Fortner, 2010; Iş̧1ldar, 2008; Oğuz et al., 2011).

The present study regards the question as to whether environmental education received in the past or in the current situation by university students in Turkey creates any differences in their environmental risk perceptions and whether these differences, if any, provide meaningful contributions to the process of environmental protection as a worthy subject for research.

\section{Environmental Education}

Even though its roots date back to such philosophers as Jean-Jacques Rousseau (1712-1778), who argued that there had to be a connection between education and environment, the importance of environmental education in the international arena was emphasized for the first time at the Intergovernmental Environmental Education Conference held for the first time in Tbilisi through the cooperation between UNESCO and UNEP in 1977. This conference added an international dimension through the attention attributed to the importance of environmental education (Tbilisi Declaration, 1977).

Environmental education is offered in the national system of education in Turkey where general education is delivered at the formal and non-formal levels (Çolakoğlu, 2010). Formal educational departments impart only activities to protect the environment to students in the scope of environmental education, but cannot create an environmental consciousness or a higher skill of thinking on such matters as environmental ethics and environmental risks. This need can only be satisfied at the higher education level (Çakır, İrez, \& Doğan, 2010). Nevertheless, there is no distinctive curriculum for environmental education at the level of higher education, whereas basic information on the environment is offered under different courses in elementary and secondary school curricula (Çolakoğlu, 2010). However, some studies demonstrate that environmental education should commence in the family and close circle of individuals and be developed further through elementary, secondary and higher education (Çabuk \& Karacaoğlu, 2003; Erdoğan, 2013; Erol \& Gezer, 2006). These studies consider environmental education as the one that covers all segments of the society and identify young generation as the 
most important target group because the young generation is considered as the group that will be influenced most adversely by today's environmental problems and thus requires knowledge, awareness, and sensitivity about environment although they are not liable for such problems. Indeed, current academic findings have indicated that higher education is the level of education where individuals are able to attain environmental consciousness (Çakır et al., 2010; Duan \& Fortner, 2010; Işıldar, 2008; Oğuz et al., 2011; Öztaş \& Kalipci, 2009; Sadık, \& Çakan, 2010; Sam et al., 2010; Şahin, Ünlü, \& Ünlü, 2016).

There is no specific nationally adopted or implemented policy concerning environmental education in Turkey at the higher education level. Universities formulate curricula and course contents in the framework of their own institutional structure. Furthermore, universities have established environmental research centers both to work on environmental issues and to act as an advisory board for public authorities. Despite all these efforts, the desired level of efficiency cannot be achieved in practice, leading to the ignorance of the interdisciplinary nature of environment and environmental issues (Çolakoğlu, 2010). Therefore, it doesn't seem to be possible to suggest that there is a nation-wide standardized educational infrastructure or practice relating to the matters of environment (Oğuz et al., 2011). However, it is important to provide mandatory environmental courses at a range of educational levels through a specific educational policy in the process of raising environmental consciousness (Yurtseven, Vehid, Köksal, \& Erdoğan, 2010), since environmental education provides relevant information to individuals in ecological sense and enables them to improve their attitudes towards the environment and to transform such attitudes into behavior.

Academic studies conducted in the field of environmental education in Turkey at the higher education level demonstrated an increase as of the year 2010 (Ateş \& Karatepe, 2013; Çakır et al., 2010; Oğuz et al., 2011; Sam et al., 2010; Şahin et al., 2016; Yurtseven et al., 2010). A part of the studies in relevant literature assessed the awareness and sensitivity of higher education students with respect to environmental issues and their environmental attitudes and environmental consciousness (Çabuk \& Karacaoğlu, 2003; Erten, 2005; Işıldar, 2008; Oğuz et al., 2011; Öcal, 2013; Selim et al., 2011; Y1lmaz \& Arslan, 2011), while a lesser number of such studies identified the risk perception in environmental matters (Kahyaoğlu, 2012; Sam et al., 2010; Yurtseven et al., 2010). Also, the low number of detailed research and analyses on the importance of environmental risk perceptions among students of vocational colleges at the higher education level in Turkey was considered to be a significant shortcoming in literature. This study attempts to fill the research gap on the relationship between environmental risk perceptions and higher education level by testing the findings of the relevant literature in the context of the university in Antalya, Turkey.

The study aims to serve for the rectification of this shortcoming. Basing on the above mentioned theoretical and empirical findings in the literature, the following hypotheses are proposed:

H1: Delivery of environmental courses to students affects their environmental risk perceptions.

H2: Departments offering education to students affect their environmental risk perceptions.

H3: The sensitivity of students on environmental matters affects their environmental risk perceptions.

\section{Method}

\section{Research Design}

The present study is a relational study with a descriptive pattern aimed to explain the relationship between university students' environment risk perceptions and environment education. Indeed, the university students will be the leaders of decision makers of institutions, and their concerns and opinions about environmental risks 
are valuable for educators to recognize, understand, and adjust to the unique culture of a society for effectively addressing and managing environmental change (Duan \& Fortner, 2010, p. 3).

\section{Research Sample}

The revised version of the questionnaire was used in the field study which was conducted with 570 university students from Electrical and Electronic Engineering, Civil Engineering, Mechanical Engineering, Computer Sciences, Environment and Agricultural Sciences departments in located in Vocational College of Technical Sciences of Akdeniz Universityin Turkey. This sample was derived from a population of 627 students from Vocational College of Technical Sciences of Akdeniz University. This sample in total represents $91 \%$ of the university students from whole population.

\section{Research Instruments and Procedure}

The environmental risk perceptions questionnaire was the basic data collection tool of this study. For the purpose of testing the above stated hypotheses a questionnaire was designed by the authors, including an environmental risk perceptions scale adapted from Altunoğlu and Atav (2009), Slimak and Dietz (2006), and Weber, Hair Jr, and Fowler (2010). This questionnaire was tested in a pilot study with 250 students and it was revised according to the feedback obtained from these students. The revised version of the questionnaire was used in the field study which was conducted through face-to-face interviews with students from January 2015 to May 2016. The resultant questionnaire about environmental risk perceptions of the university students consisted of three parts. First part contained some relevant information about the some demographic information; second part contained environmental education of the students; and third part contained environmental risk perceptions.

\section{Validity and Reliability}

The gathered data from questionnaires are analyzed through a factor analysis of principal component extraction method with a Varimax-rotation in SPSS 21.0, yielding 7 items for ecological, 6 items for chemical, 4 items for biological and 4 items for global with factor loadings over 0.50 as in Table 1 . With these 21 items measuring environmental risk perceptions, the cumulative variance explained is $61.10 \%$, which is above the acceptable limit of $60 \%$. The KMO measure of sampling adequacy is 0.79 which is an acceptable value and close to 1 . The value of Bartlett test of sphericity which indicates sufficient correlation between the variables is 827.71 and it is significant $(p=0.000)$. The factor loadings for the items range from 0.57 to 0.80 . Consequently all the mentioned results of factor analysis are in acceptable range (Lewis-Beck, 1994).

Table 1

Factor Analysis Results of Environmental Risk Perception Scale

\begin{tabular}{|c|c|c|c|c|}
\hline Factor & Ecological & Chemical & Biological & Global \\
\hline Loss of wetlands & 0.57 & & & \\
\hline Invasive species & 0.75 & & & \\
\hline Genetically modified agricultural products & 0.80 & & & \\
\hline Forest sector & 0.69 & & & \\
\hline The construction of dams & 0.76 & & & \\
\hline Chemical pollution of inland waters & 0.78 & & & \\
\hline Eutrophication & 0.77 & & & \\
\hline Hazardous waste & & 0.74 & & \\
\hline Radiation & & 0.73 & & \\
\hline
\end{tabular}


Table 1 continued

\begin{tabular}{|c|c|c|c|c|}
\hline Factor & Ecological & Chemical & Biological & Global \\
\hline Heavy metals & & 0.79 & & \\
\hline Persistent organic compounds & & 0.69 & & \\
\hline Sewage & & 0.76 & & \\
\hline Pesticides & & 0.67 & & \\
\hline Sport fishing & & & 0.58 & \\
\hline Commercial fishing & & & 0.66 & \\
\hline Overgrazing & & & 0.74 & \\
\hline Population growth & & & 0.76 & \\
\hline Acid rain & & & & 0.57 \\
\hline Greenhouse effect & & & & 0.62 \\
\hline Ozone layer depletion substances & & & & 0.75 \\
\hline Oil extraction & & & & 0.76 \\
\hline Eigenvalues & 2.60 & 2.34 & 3.19 & 2.04 \\
\hline Cumulative variance explained (\%) & 18.24 & 32.01 & 50.25 & 61.10 \\
\hline
\end{tabular}

As can be seen in Table 2, the Cronbach Alpha values of the factors range from 0.75 to 0.70 suggesting satisfactory levels of construct reliability, since Cronbach Alpha values equal to or higher than 0.70 , indicate the reliability of scales (Hair et al., 1998) used in this study. Average values of environmental risk perception types are also indicated in Table 2.

Table 2

Cronbach Alpha Values and Descriptive Statistics

\begin{tabular}{lllllll}
\hline Environmental risk perception dimensions & Mean & S.D. & $\begin{array}{l}\text { Cronbach } \\
\text { Alpha }\end{array}$ & $\begin{array}{l}\text { Number of } \\
\text { items }\end{array}$ & N & Scale type \\
\hline Ecological & 3.65 & 0.63 & 0.71 & 7 & 570 & LS* $^{*}$ \\
Chemical & 3.72 & 0.62 & 0.70 & 6 & 570 & LS* $^{*}$ \\
Biological & 3.37 & 0.69 & 0.70 & 4 & 570 & LS* $^{*}$ \\
Global & 4.08 & 0.64 & 0.75 & 4 & 570 & LS* \\
\hline
\end{tabular}

Note. LS*: Likert Scale (5-point : $1=$ strongly disagree to $5=$ strongly agree).

According to Table 2, global risk perception has the highest average value $(4.08 \pm 0.64)$, followed by chemical risk perception (3.72 \pm 0.62$)$, ecological risk perception $(3.65 \pm 0.63)$ and biological risk perception $(3.37 \pm 0.69)$ receiving the lowest value.

\section{Data Analysis}

The research data were analyzed through use of the statistical package program. First, the study confirmed whether data provided the general requirements of the parametric tests. In addition, the Kolomogrov Smirnov test assessed whether the data were distributed normally $(K S Z=0.14, p>0.05)$. As a result of the analyses, the data demonstrated normal distribution. Second, descriptive statistics, correlations, $T$-test and analysis of variance were used during the data analysis.

\section{Results}

\section{Sample Profile}

The first part of questionnaire contained demographic information about the students. Sixty percent of all respondents were male. The respondents' ages were mostly between 16 and 25 , and nearly all of the 
respondents were single. Of the 570 participants who noted level of education, $58 \%$ reported first year of university and $42 \%$ reported second and above years of university. The scope of the research examined the students within the programs they attend 50\% electrical and electronic engineering, 20\% environment and agriculture sciences, with the remaining $30 \%$ civil engineering, mechanical engineering, computer sciences.

\section{Descriptive Findings}

The second part of questionnaire contained environmental education of the university students. The specific questions were dedicated to the respondents' perception on environmental topics and environmental education. Eighty-eight percent of the students in the sample stated that they had received education on environmental matters only by their families since their childhood and had not received any environmental education in their years preceding university. Sixty percent of the students expressed that they had taken a course on the environment at least once during their graduate education.

The students were the asked about their opinions concerning the mandatory or optional nature of environmental courses in educational departments and the level of educational life at which such education should be provided. Ninety percent of the students believe that environmental courses should be taught mandatorily throughout the educational life. Thirty percent of the students who gave this response attended electrical and electronic engineering programmes; Thirty percent environmental and agricultural sciences; and $40 \%$ mechanical and civil engineering or computer sciences. The students were asked the question "Do you believe that your vocational college/programme showes sufficient sensitivity towards environmental problems and relevant courses?" with respect to the higher education institution they were attending. Ninnty-nine percent of the students stated they believed that their schools showed sufficient sensitivity towards environmental problems and relevant courses.

Finally, the students were asked whether they were sensitive towards the environment. Seventy percent of the students indicated that they were extremely sensitive towards the environment and relevant issues. In addition, the students were asked whether they knew about the prominent non-governmental organizations that were active in the field of environment in Turkey or whether they were members of such organizations. The students indicated the most commonly known non-governmental organizations as TEMA (The Turkish Foundation for Combating Soil Erosion, for Reforestation and the Protection of Natural Habitats), Greenpeace and DHKD (World Wildlife Foundation). Only 10\% of the students specified that they were members to the non-governmental organizations listed in the form. All students who responded to this question attend the department on environmental and agricultural sciences.

\section{Correlations}

Table 3

Correlation Tests

\begin{tabular}{lllll}
\hline Environmental risk perception dimensions & 1 & 2 & 3 & 4 \\
\hline 1. Ecological & 1 & $0.61^{*}$ & $0.55^{*}$ & $0.69^{*}$ \\
2. Chemical & $0.61^{*}$ & 1 & $0.64^{*}$ & $0.72^{*}$ \\
3. Biological & $0.55^{*}$ & $0.64^{*}$ & 1 & $0.67^{*}$ \\
4. Global & $0.69^{*}$ & $0.72^{*}$ & $0.67^{*}$ & 1 \\
\hline
\end{tabular}

Correlation tests between the factors are shown in Table 3. It contains the intercorrelations among the factors used in the study. The correlation matrix shows that the four dimensions of environmental risk 
perception are strongly intercorrelated. These scores are in accordance with the literature (Altunoğlu \& Atav, 2009; Slimak \& Dietz, 2006; Sam et al., 2010).

\section{T-Test and Analysis of Variance}

$T$-test and analysis of variance were performed to identify if the environmental risk perceptions of students varied depending on the following variables: taking a course about environment during university education, the department attended at the university, the education level of their parents, and their sensitivity to the environment. The effect of taking at least 1 course about environment during university education on the environmental risk perceptions of the students was analyzed by $T$-test (Table 4). The analysis results represent a significant difference between the two groups divided in terms of their experience with at least 1 course on the environment. The findings showed that all averages pertaining to environmental risk perceptions were significantly higher among those who had taken a course on the environment than those of students who had not received such a course. A review of the average and standard deviation values pertaining to the dimensions of environmental risk perceptions revealed that the global risk perception $(4.14 \pm 0.46)$ had the highest average than the other dimensions. In this situation, taking an environmental course can be stated to have the highest impact on the dimension of global risk perception.

Table 4

The Relationship Between University Education and Environmental Risk Perceptions

\begin{tabular}{lllll}
\hline \multirow{2}{*}{ Environmental risk perception dimensions } & \multicolumn{2}{l}{ University education } & \multicolumn{2}{c}{ P value } \\
\cline { 2 - 5 } & Yes & No & & $0.024^{*}$ \\
\hline Ecological & $3.86 \pm 0.50$ & $3.02 \pm 0.32$ & 2.27 & $0.004^{*}$ \\
Chemical & $4.05 \pm 0.52$ & $3.82 \pm 0.34$ & 2.89 & $0.001^{*}$ \\
Biological & $3.74 \pm 0.59$ & $3.00 \pm 0.44$ & 2.22 & $0.003^{*}$ \\
Global & $4.14 \pm 0.46$ & $3.97 \pm 0.39$ & 2.96 & \\
\hline
\end{tabular}

Notes: $* p<0.005$.

The departments attended by the university students and their effects on their environmental risk perceptions were examined through variance analysis. According to the analysis, it was found out that the departments attended by the students had an impact on all variables of environmental risk perception. Departments that lead to differentiation in the dimensions of environmental risk perceptions were analyzed through Tukey-B test. As a result of the analysis, students of the department on environmental and agricultural sciences were observed to have a higher average in environmental risk perception than those attending other departments. As regards the averages, it was found that the students of the department on environmental and agricultural sciences had the highest average in the global risk perception (Mean $=4.25 ; p=0.000^{* *}$ ) among the dimensions.

The sensitivity of students towards environmental issues was analyzed in terms of its impact on environmental risk perceptions through the $t$-test (Table 6). As a result of the analysis, a significant difference was identified between students who claimed to be sensitive to the environment and students who answered this question negatively. The findings showed that all averages pertaining to the environmental risk perception of environmentally sensitive students were higher than those of the other group. A review of the average and standard deviation values pertaining to the dimensions of environmental risk perceptions revealed that the global risk perception had the highest average than the other dimensions $(4.57 \pm 0.42)$. In other words, environmentally sensitive students can be stated to be sensitive mostly towards global environmental risk factors. 
Table 5

The Relationship Between University Departments and Environmental Risk Perceptions

\begin{tabular}{|c|c|c|c|c|c|}
\hline \multirow{3}{*}{$\begin{array}{l}\text { Environmental risk } \\
\text { perception dimensions }\end{array}$} & \multicolumn{3}{|c|}{ Departments } & \multirow{3}{*}{ F value } & \multirow{3}{*}{$P$ value } \\
\hline & $\begin{array}{l}\text { Environment and } \\
\text { agriculture sciences }\end{array}$ & Electricity and electronic & $\begin{array}{l}\text { Civil engineering, } \\
\text { mechanical engineering, } \\
\text { computer sciences }\end{array}$ & & \\
\hline & Means & Means & Means & & \\
\hline Ecological & 3.41 & 3.33 & 3.20 & 3.799 & $0.012 *$ \\
\hline Chemical & 3.66 & 3.55 & 3.47 & 4.370 & $0.005 * *$ \\
\hline Biological & 3.00 & 2.99 & 2.93 & 3.772 & $0.011 *$ \\
\hline Global & 4.25 & 3.87 & 3.82 & 4.774 & $0.000 * *$ \\
\hline
\end{tabular}

Notes: $* p<0.05 * * p<0.005$.

Table 6

The Relationship Between Sensitivity of Students Towards Environmental Issues and Environmental Risk Perceptions

\begin{tabular}{|c|c|c|c|c|}
\hline \multirow[t]{2}{*}{ Environmental risk perception dimensions } & \multicolumn{2}{|c|}{$\begin{array}{c}\text { Sensitivity of students towards } \\
\text { environmental issues }\end{array}$} & \multirow[t]{2}{*}{ - T value } & \multirow[t]{2}{*}{$P$ value } \\
\hline & Yes & No & & \\
\hline Ecological & $3.94 \pm 0.50$ & $3.00 \pm 0.41$ & 2.18 & $0.001 *$ \\
\hline Chemical & $4.23 \pm 0.51$ & $4.12 \pm 0.35$ & 2.85 & $0.001 *$ \\
\hline Biological & $3.52 \pm 0.46$ & $3.18 \pm 0.43$ & 2.18 & $0.005^{*}$ \\
\hline Global & $4.57 \pm 0.42$ & $4.23 \pm 0.34$ & 2.93 & $0.005^{*}$ \\
\hline
\end{tabular}

Notes. ${ }^{*} p<0.005$.

Therefore, according to the findings of the $t$-test and ANOVA analysis hypotheses $\mathrm{H} 1, \mathrm{H} 2$, and $\mathrm{H} 3$ are accepted.

\section{Discussion and Conclusion}

Industrializations and modernization started to disrupt ecological balances around the whole world. Environmental issues including the exhaustion of gene and energy resources, extinction of species, and reduction in arable agricultural land have become global problems. Now, the perception of individuals towards environmental issues and the effect of education on such perceptions have become prominent in the academic field. The importance of education in understanding the risks that threaten the environment and suggesting solutions for such risks and raising awareness on environmental matters has become an important research question. Research studies undertaken in Turkey demonstrate that environmental education should commence in the family and close circle of individuals and be developed further through elementary, secondary, and higher education. The current academic findings, however, demonstrate that higher education is the level of education where individuals are able to attain environmental awareness. As an example, Sam et al. (2010) specified the importance of higher education specifically in the process of informing individuals on environmental matters, raising their consciousness and instituting permanent changes in behavior in this context in their study on students of a vocational college. However, it is striking that there are only a few studies and analyses conducted on the importance of environmental risk perceptions among students of post-secondary vocational schools at higher education level in Turkey. A part of the studies in relevant literature assessed the awareness of higher education students with respect to environmental issues and their environmental attitudes 
and environmental consciousness, while a lesser number of such studies identified the risk perception in environmental matters. Therefore, the aim of the present study is to identify whether environmental education created a difference in environmental risk perception and whether such differences, if any, contributed to the process of environmental protection in a meaningful manner. The study results are given below.

Students responding to the study stated that taking at least one course on environment during their university education had an impact on all aspects of their environmental risk perception. In contrast with Sam et al. (2010), the averages observed in the present study indicated that environmental education had the highest impact at the level of significance on the global risk perception. This result is consistent with the second hypothesis of the study and demonstrate that specifically the students attending the department on environmental and agricultural sciences were sensitive towards the impact of acid rain on forests, depletion of the ozone layer by the gases used in refrigerators, the increase in ultraviolet sunlight, and the leakage of toxic waste into rivers and soil. There are signals showing that the department aiming at educating qualified intermediate technical labour force required in the field of environmental protection and control in Turkey has achieved the intended level of environmental education through the current curriculum. The point that must be duly underlined in this context is the fact that students of other departments of the vocational college not linked directly with the environment also demonstrated a level of environmental risk perception. This result can be interpreted to imply that the college administration disseminated environmental consciousness throughout the school not only with formal education, but also through non-formal learning processes.

Finally, environmentally sensitive students were identified to be sensitive mostly towards global environmental risk factors. The great majority of students expressed that university education had improved their sensitivity towards environmental matters and they knew about the prominent non-governmental organizations active in the field of environment and became members to such organizations owing to their education.

In summary, the results of the present study indicate that the formal education and non-formal learning processes offered at vocational colleges with respect to matters concerning the environment have an impact upon students. The Vocational College of Technical Sciences under Akdeniz University in Turkey is among remarkable schools with both its number of students, departments, academic and administrative personnel, and its quality of education. The post-secondary vocational school that assumes important tasks in the education of intermediary labour force has been taking significant steps to raise environmental awareness of all students by providing education and training about "environment" to all students. In fact, the present study gives way to the opinion that the additions of courses on environmental matters to all departments create a difference in the environmental risk perceptions of students. The comparison of results through the use of the same question form at different vocational colleges in Turkey in further research studies is striking in terms of the efforts of vocational colleges to review their curricula. In the forthcoming research process, the plan is to reinterpret the results through the employment of qualitative research methods (interview, observation, etc.) and to identify whether students demonstrate environmental risk perceptions in different areas.

\section{References}

Ağbuğa, F. (2016). Çevre Sorunlarına Etik Bir Yaklaşım: Felsefi Bir Sorgulama. Yüksek Lisans Tezi. Pamukkale Üniversitesi /Sosyal Bilimler Enstitüsü, Denizli.

Anantho, S. (2008). Risk perception and sustainable development in Thailand. http://www.unescobkk.org

Ateş, M., \& Karatepe, A. (2013). The analysis of university students' perceptions towards "environment" concept with the help of metaphors. International Journal of Social Science, 6(2), 1327-1348. doi:dx.doi.org/10.9761/JASSS_642. 
Beck, U. (1992). Risk society, towards a new modernity. London: Sage Publications.

Böhm, B., \& Pfister, H. R. (2000). Action tendencies and characteristics of environmental risks. Acta Psychologica, 104, $317-337$.

Çabuk, B., \& Karacaoğlu, C. (2003). Üniversite Öğrencilerinin Çevre Duyarlılıklarının İncelenmesi. Ankara Üniversitesi Eğitim Bilimleri Fakültesi Dergisi, 36(1-2), 189-198.

Çakır, M., İrez, S., \& Doğan, Ö. K. (2010). Understandings of current environmental issues: Turkish case study in six teacher education colleges. Educational Studies, 1(36), 21-35.

Çolakoğlu, E. (2010). Haklar Söyleminde Çevre Eğitiminin Yeri ve Türkiye'de Çevre Eğitiminin Anayasal Dayanakları. TBB Dergisi, 88, 151-171.

Doğan, M. (1997). Ulusal Çevre Eylem Planı: Eğitim ve Katılım. DPT: Türkiye Çevre Vakfi.

Duan, H., \& R. Fortner. (2010). A cross-cultural study on environmental risk perception and educational strategies: Implications for environmental education in China. International Electronic Journal of Environmental Education, 1(1), 1-19.

Erdoğan, N. (2013). Environmental worldviews in higher education: A case study of Turkish college students. Procedia-Social and Behavioral Sciences, 106(10), 1086-1095.

Erol, G. H., \& Gezer, K. (2006). Sınıf Öğretmenliği Öğretmen Adaylarına Çevreye ve Çevre Sorunlarına Yönelik Tutumları. International Journal of Environmental \& Science Education 1(1), 65-77.

Erten, S. (2005). Okul Öncesi Öğretmen Adaylarında Çevre Dostu Davranışların Araştırılması. Hacettepe Üniversitesi Eğitim Fakültesi Dergisi, 28(2005), 91-100,

Fernández-Manzanal, R., Rodríguez-Barreiro, L., \& Carrasquer, J. (2007). Evaluation of environmental attitudes: Analysis and results of a scale applied to university students. Science Education, 91(6), 988-1009.

Işı1ldar, G. Y. (2008). Meslek Yüksekokulları Boyutunda "Çevre Eğitimi” nin Çevreci Yaklaşımlar ve Davranışlar Üzerindeki Etkilerinin Değerlendirilmesi. Türk Eğitim Bilimleri Dergisi, 6(4), 759-778.

Kahraman, M. (2002). Tehlikeli Maddeler ve Çevresel Risk Değerlendirme Yaklaşımları-Örnek Uygulama. Yüksek Lisans Tezi. İTÜ /Fen Bilimleri Enstitüsü, İstanbul.

Kahyaoglu, M. (2012). The relationship between teacher candidates' environmental risk perceptions and problem solving skills. Journal of Education and Future, 2(2012), 93-104.

Kasperson, R. E., Kasperson, J. X. , \& Dow, K. (2001). Vulnerability, equity, and environmental changes. In J.X. Kasperson and R.E. Kasperson(Eds.), Global Environmental Risk (pp. 247-272). Tokyo: United Nations University Press and Earthscan.

Kırcı, H. (2014). Hedonik Tüketim Davranışları ve Toplumsal Etkileri. Paradoks: Ekonomi, Sosyoloji ve Politika Dergisi, 10(1), $82-100$.

Lai, J. C. L., \& Tao, J. (2003). Perception of environmental hazards in Hong Kong Chinese. Risk Analysis, 23(4), 669-684.

Monroe, M. C., Andrews, E., \& Biedenweg, K. (2007). A framework for environmental education strategies. Applied Environmental Education and Communication, 6(3-4), 05-16.

Oğuz, D., Çakıc1, I., \& Kavas, S. (2011). Yükseköğretimde Öğrencilerin Çevre Bilinci. Süleyman Demirel Üniversitesi Orman Fakültesi Dergisi, 12(1), 34-39.

Öcal, T. (2013). Sosyal Bilgiler Öğretmen Adaylarının Çevre Sorunlarına Yönelik Tutumlarının Belirlenmesi. Marmara Coğrafya Dergisi, 27, 333-352.

Öztaş, F., \& Kalipci, E. (2009). Teacher candidates' perception level of environmental pollutant and their risk factors. International Journal of Environmental and Science Education, 4(2), 185-195.

Payne, P. (2016). The politics of environmental education. critical inquiry and education for sustainable development. The Journal of Environmental Education, 47(2), 69-76, doi: 10.1080/00958964.2015.1127200.

Riechard, D., Peterson, S. (1998). Perception of environmental risk related to gender, community socioeconomic setting, age, and locus of control. The Journal of Environmental Education, 30(1), 11-19, doi: 10.1080/00958969809601858.

Sadık, F., \& Çakan, H. (2010). Biyoloji Bölümü Öğrencilerinin Çevre Bilgisi ve Çevre Sorunlarına Yönelik Tutum Düzeyleri. Çukurova Üniversitesi Sosyal Bilimler Enstitüsü Dergisi, Cilt:19, Sayı:1, ss:351-365.

Sam, N., Gürsakal, S., \& Sam, R. (2010). Üniversite Öğrencilerinin Çevresel Risk Algısı ve Çevresel Tutumlarının Belirlenmesi Assessing Environmental Risk Perceptions And Environmental Attitudes Of University Students. Akademik BakıŞ Uluslararası Hakemli Sosyal Bilimler e-Dergisi, 20, 1-16. http://www.akademikbakis.org/eskisite/20/13.pdf

Selim, S., Karakuş, N., Elkan, S., \& Selim, C. (2011). Meslek Yüksekokulu Öğrencilerinin Çevre Sorunlarına İlişkin Görüş ve Tutumlarının Değerlendirilmesi: Ortaca Meslek Yüksekokulu Örneği. Süleyman Demirel Üniversitesi Orman Fakültesi Dergisi, 12(2), 148-154. http://dergipark.ulakbim.gov.tr/sduofd/article/view/1089002617/1089002604

Slimak, W. M., \& Dietz, T. (2006). Personal Values, Beliefs, and Ecological Risk Perception, Risk Analysis, 26(6), $1689-1705$. 
Steg, L., \& Sievers, I. M. (2000). Cultural theory and individual perceptions of environmental risks. Environment and Behavior, 32(2), 250-269.

Şahin, S. H., Ünlü, E., \& Ünlü, S. (2016). Öğretmen Adaylarının Çevre Okuryazarlık Farkındalık Düzeylerinin İncelenmesi. Education Sciences, 11(2), 82-95.

Talay, İ., G., S. \&Akpınar, N. (2004). On the status of environmental education and awareness of undergraduate students at Ankara university, Turkey. International journal of Environment and Pollution, 21(3), 293-308.

Tbilisi Declaration. (1977). www.gdrc.org/uem/ee/tbilisi.html, 2016.

Van der L., S. (2015). The social-psychological determinants of climate change risk perceptions: towards a comprehensive model. Journal of Environmental Psychology, 41, 112-124.

Weber, J., H. Jr, J. \& Fowler, C. (2000) Developing a measure of perceived environmental risk. The Journal of Environmental Education, 32(1), 28-35, doi: 10.1080/00958960009598669

Yılmaz, V., \& Arslan, T. (2011). Üniversite Öğrencilerinin Çevre Koruma Vaatleri ve Çevre Dostu Tüketim Davranışlarının İncelenmesi. Anadolu Üniversitesi Sosyal Bilimler Dergisi. 11(3), 1-10.

Yurtseven, E., Vehid, S., Köksal, S., \& Erdoğan, M. S. (2010). İstanbul Üniversitesi Sağllk Hizmetleri Meslek Yüksek Okulu Öğrencilerinin Çevresel Riskler Konusundaki Duyarlılıkları. FÜ Sağ. Bil. Tıp Dergisi, 24(3), 193-199.

Young, L-H, K., H-W, \& Chiangc, C-F. (2015). Environmental health risk perception of a nationwide sample of Taiwan college students majoring in engineering and health sciences. Human and Ecological Risk Assessment:21(2):307-326.

Zhang, L. H., Mol, G. Z., A. P. J., \& Lu, Y. L. (2012). Public perceptions of environmental risk in China. Journal of Risk Research. DOI: 10.1080/13669877.2012.726240 